\title{
Interproximal Papillae Reconstruction around Implant Using Subepithelial Connective Tissue Graft in Maxillary Anterior Region: A Case Series
}

\author{
Satish Gupta ${ }^{1}$, Vikas Deo ${ }^{2}$, Cecil Williams ${ }^{3}$ \\ ${ }^{1}$ Department of Periodontology and Implantology, S.P Dental College, Wardha, India. \\ ${ }^{2}$ Department of Periodontology and Implantology, Government Dental College, Jaipur, India. \\ ${ }^{3}$ Department of Prosthodontics, Daswani Dental College, Kota, India.
}

\author{
Corresponding Author: \\ Vikas Deo \\ 224, Padmawati B, Kings Road \\ Jaipur, 302019, \\ India \\ Phone: +919950991918 \\ Fax: +911512230316 \\ E-mail: drvikas 81@yahoo.com
}

\begin{abstract}
Objectives: The present study was undertaken to evaluate the effectiveness of interproximal papillae reconstruction around early loaded single implant using subepithelial connective tissue graft in maxillary anterior region.

Material and Methods: Ten systemically healthy patients (mean age $=29.3$ [SD 7.9] years) in need of dental implants in maxillary anterior region were included in the study. Interproximal papillae reconstruction around single implant using subepithelial connective tissue graft was applied. The donor palatal tissue was harvested by a 'trap door approach'. Subepithelial connective tissue graft was inserted in the pouch created on mesial and distal site of implant. Clinical and radiographic parameters were recorded around the each implant, including papillary height and papillary gingival contour, at baseline, 3 and 6 months after operation.

Results: The mesial papilla height was increased by 1.9 (SD 0.87) mm, $\mathrm{P}=0.005$ at 3 month and maintained at 1.5 (SD 0.97 ) $\mathrm{mm}, \mathrm{P}=0.007$ at 6 months. The distal papilla height was increased by 2 (SD 0.66) $\mathrm{mm}, \mathrm{P}=0.004$ at 3 month and maintained at $1.2(\mathrm{SD} 0.78) \mathrm{mm}, \mathrm{P}=0.010$ at 6 months. Assessment of papilla contour index showed $90 \%$ aesthetic success both for mesial and distal papilla at 6 months.

Conclusions: It can be concluded that subepithelial connective tissue graft may be used to successfully augment the gingival papillae adjacent to single tooth implant restoration.
\end{abstract}

Keywords: dental papilla; dental implant; dental implant, single-tooth; early dental implant loading; tissue grafts; tissue transplants.

Accepted for publication: 10 April 2012.

To cite this article:

Gupta S, Deo V, Williams C. Interproximal Papillae Reconstruction around Implant Using Subepithelial Connective Tissue Graft in Maxillary Anterior Region: A Case Series.

J Oral Maxillofac Res 2012 (Apr-Jun);3(2):e1

URL: http://www.ejomr.org/JOMR/archives/2012/2/e1/v3n2e1ht.pdf

doi: $10.5037 /$ jomr.2012.3201 


\section{INTRODUCTION}

In the past two decades, replacement of missing teeth with implant supported prostheses has become a widely accepted treatment for the oral rehabilitation of partially or fully edentulous patients. High clinical success rates with the original implant protocols have given clinicians and researcher's confidence to further develop and refine the osseointegrated technique and use of implants in increasingly more challenging situations and on broader indications $[\underline{1}, \underline{2}]$. Earlier a submerged healing period of 3 - 6 months was considered a prerequisite for achieving osseointegration of titanium implants. However, the time required for treatment, the need for additional surgical procedures, and the need for indefinite period of temporization is disadvantages of the standard protocol. During the past $10-15$ years, clinical studies have reported the successful outcome of early and immediate loading of implants in various clinical situations [3].

With the growing use of implant-supported oral rehabilitation in the partially edentulous patient and single tooth restoration, emphasis has now changed towards achieving predictable aesthetic success particularly in maxillary anterior region and patients who may show the peri-implant soft tissue when smiling and speaking [4]. Establishing a soft tissue contour with an intact interproximal papillae around implant retained restoration is challenging and failure to achieve these harmonious relationships of soft tissue around implant may lead to unaesthetic appearance [5].

Various soft-tissue surgical procedures have been introduced in an attempt to re-create the papillae around implants. Price and Price [ $[\underline{6}$ presented a case report describing the use of subepithelial connective tissue graft (SCTG) to restore the gingival papillae and augment soft tissue ridge adjacent to dental implant. Azzi et al. [7] proposed periodontal plastic surgical procedure to improve the soft tissue aesthetics. Therefore, the present study was undertaken to evaluate the effectiveness of interproximal papillae reconstruction around early loaded single implant using subepithelial connective tissue graft in maxillary anterior region.

\section{MATERIAL AND METHODS}

\section{Study population}

Ten subjects ( 8 males and 2 females; age 19 to 45 years, mean age $=29.3[$ SD 7.9] years) in need of dental implants were consecutively enrolled in the study from April 1, 2010 to June 1, 2012. All participants have read and signed informed consent form.
The study protocol was approved by the Ethical Committee of D.M.I.M.S, Wardha. Subjects with severe systemic health problems, e.g., uncontrolled diabetes, immunodeficiency diseases, and heavy smokers (more than 10 cigarettes a day), were excluded from the study. A relationship between implant complications and smoking has proved to be a significant factor [9]. The subjects had to fulfil the following criteria to be included in the study: good general health, a need for single implant placement in the maxillary anterior sextant, an absence of adjacent implant sites or prosthetic restorations, and the availability of complete clinical records. The width of alveolar process at implant recipient site was stated to be $\geq 6 \mathrm{~mm}$ and height $\geq 10$ $\mathrm{mm}$. The bone quality should be D-1, D-2 or D-3 [8].

Seven subjects had maxillary central incisor missing and three had maxillary canine missing. All the patients were treated by one stage implant and early loading protocol along with reconstruction of papillae by SCTG. Ten screw-shaped, titanium integrated surface (Hi-Tec Implants ${ }^{\circledR}$, Herzlia, Israel) were placed accordingly. The implant surgery was done by one oral surgeon and restorations were made by one prosthodontist. The sites were evaluated at three time points: at baseline, at 3 and 6 months after dental implants placement.

\section{Initial therapy}

After proper examination and diagnosis, initial therapy consisting of oral hygiene instructions, supra- and subgingival scaling, and root planing were performed. Plaque control instructions were repeated until the patients achieve a plaque score of $\leq 1$. Before entering the surgical phase, diagnostic cast of each patient was prepared to establish maxillary-mandibular relationship. A diagnostic wax up of the missing natural tooth and a clear acrylic resin surgical drill guide was prepared to facilitate correct implant placement. The clinical photograph, periapical and panoramic radiographs were obtained.

Recording of clinical indices were carried out by the operator and the cross examiner in all the patients. Mean of these values were obtained for the assessment of the result.

\section{Periimplant tissue assessment Clinical assessment}

Clinical parameters recorded around each implant includes modified plaque index (PI) [10], modified bleeding index (PBI), probing pocket depth (PPD) and clinical attachment level (CAL) $[11,12]$. PPD and CAL were recorded at four sites (i.e. mesial, buccal, distal and lingual) of each implant by using a calibrated 
manual periodontal probe (UNC 15, Hu-Friedy, Chicago, USA). The implant shoulder was used as a reference line for the location of the mucosal margin. In addition, the width of the keratinized gingiva (WKG) was assessed on mid-buccal aspect of each implant.

\section{Radiographic assessment}

Photographic measurements of radiographs were obtained at baseline, 3 months and 6 months after operation. Photographic measurements were transferred to data sheets and analyzed statistically. To assess the changes at the interproximal alveolar crestal bone height, the distance from the implant shoulder to the most coronal bone to implant contact (DIB) was determined both at the mesial and distal aspect of each implant (Figures 1 and 2) [13-15]. Chances of having complete papillae around single tooth implant supported crown are minimal when distance between contact points to the crest of the alveolar bone is more than $5 \mathrm{~mm}$ [16].

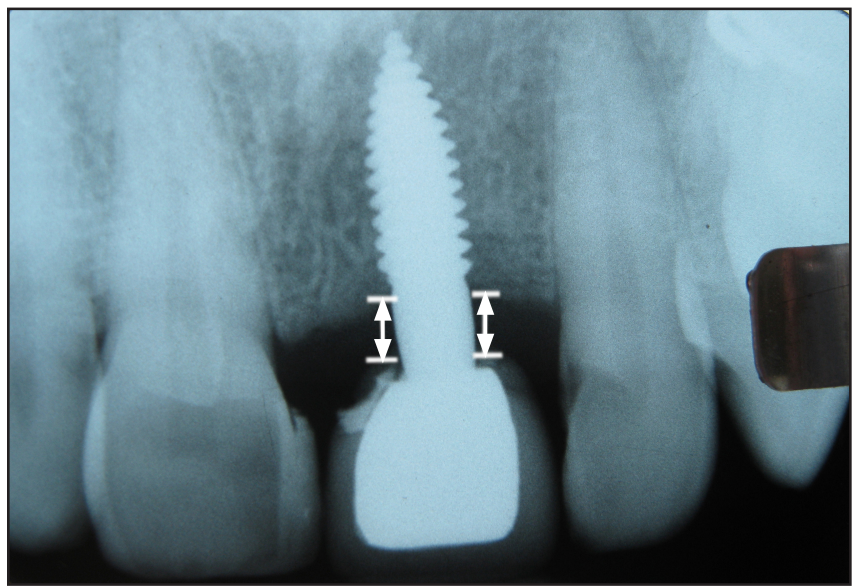

Figure 1. Periapical radiograph of patient \#1 showing the distance from the implant shoulder to the most coronal bone to implant contact (DIB) both at the mesial and distal aspect of the implant (white arrows).

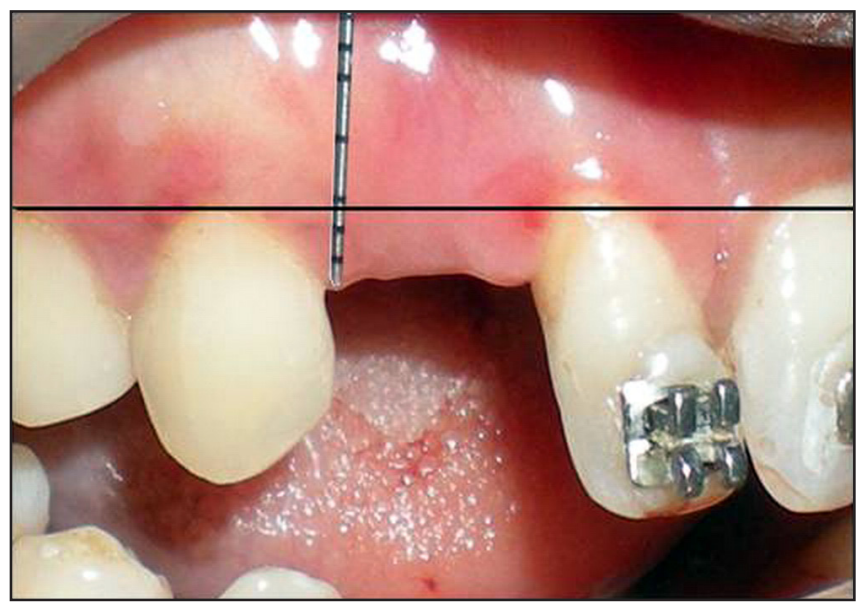

Figure 3. Papillary height measurement at baseline.

\section{Interproximal / interimplant papillae measurement Papillary height measurement}

In order to measure the soft tissue changes in an apicocoronal dimension, clinical photograph were obtained before surgery as well as at both periods of follow-up. The reference line was drawn over the preoperative photograph from the most apical points of gingival margins on the tooth [4]. Similarly, reference line was reproduced postoperatively on clinical photograph and any change in vertical dimension of the soft tissue height both on mesial and distal surface were calculated by comparing preoperative and postoperative measurements (Figures 3 and 4).

\section{Papillae contour measurement}

Papillae contour was measured by using papilla index score (PIS) for mesial and distal papillae from the clinical photograph taken preoperatively and postoperatively

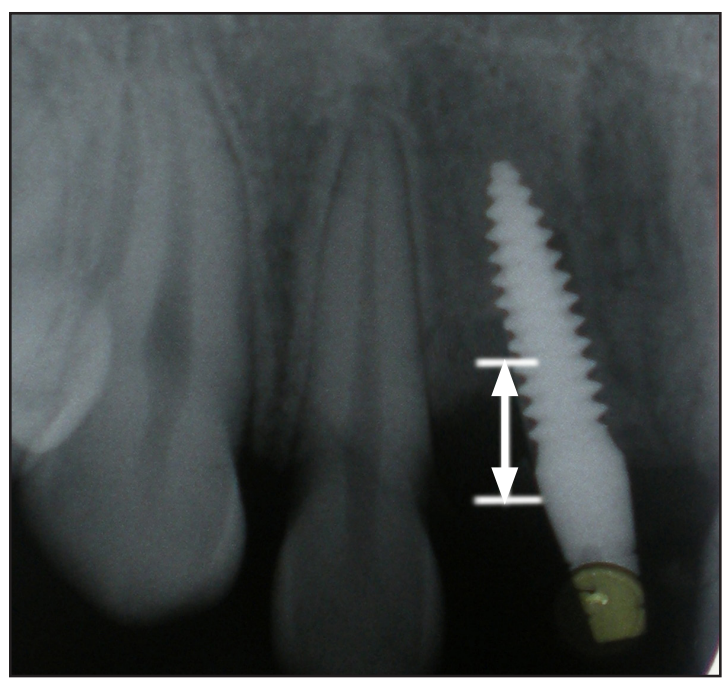

Figure 2. Periapical radiograph of patient \#2 showing the distance from the implant shoulder to the most coronal bone to implant contact (DIB) at the distal aspect of the implant (white arrow).

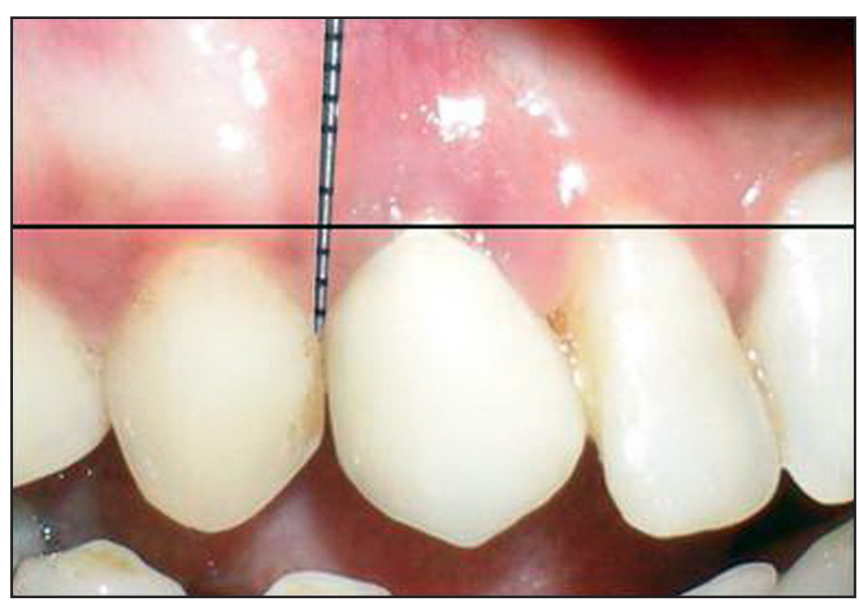

Figure 4. Papillary height measurement at 6 months follow-up. 
(at 3 month and 6 month). The index designates four different levels indicating the amount of papilla present $[12,17]$. The assessment was measured from reference line drawn through the highest gingival curvature on the adjacent teeth on the buccal side. The distance from this line to contact point of the natural tooth/crown were assessed both on mesial and distal surface of implant (Figures 5 and 6).

\section{Other soft tissue assessment}

Discoloration of the soft tissue above the restoration and visible titanium margins was identified as present or not present. Signs of severe inflammation or fistulas were also noted. A comparison was made between the situation at the time of placement and at follow-up. The size of the papilla was determined and classified as having increased, remained the same, or been reduced during the follow-up period; and a change of the colour of the soft tissue and/or visible titanium if noted.

\section{Surgical procedure Implant placement}

After infiltration with local anesthetic, a crestal incision was made along the crest of the ridge using Bard-Parker $\# 12$ or \#15C surgical blade, bisecting the existing keratinized mucosa but without splitting the adjacent papillae. Vertical releasing incisions were made extending to the vestibule. The papillae of the adjacent teeth were not included in the flap design (Figure 7). A full thickness flap was raised buccally and palatally exposing the underlined ridge of the implant site. A surgical drill guide was used for the precise placement of the pilot drill. After pilot drill application, the osteotomy was prepared with the corresponding size of parallel drill. The implants were placed in the recipient site by means of an insertion device. The implant neck was positioned at the crestal bone level or slightly submerged. The healing abutment extension of the implant was placed in such a way that the head of the implant protruded about 2 to $3 \mathrm{~mm}$ from the bone crest.

\section{Papilla reconstruction procedure Harvesting of subepithelial connective tissue graft (SCTG)}

A sterile template was utilized to obtain the desired dimensions and shape of the SCTG from the premolarmolar area. The donor palatal tissue was harvested by a 'trap door approach' from the area between the maxillary first molar and maxillary cuspid. A template was placed at the recipient site to harvest a graft of

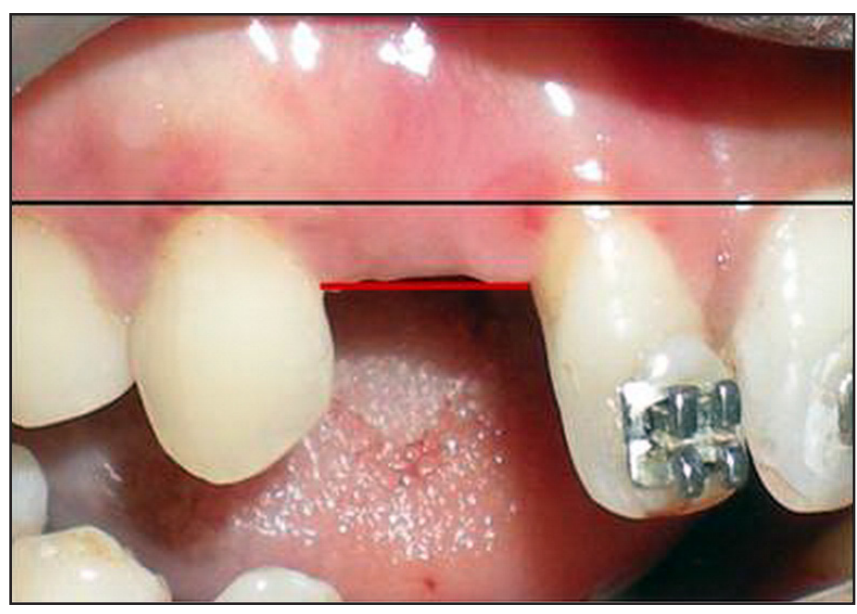

Figure 5. Papillae contour measurement at baseline.

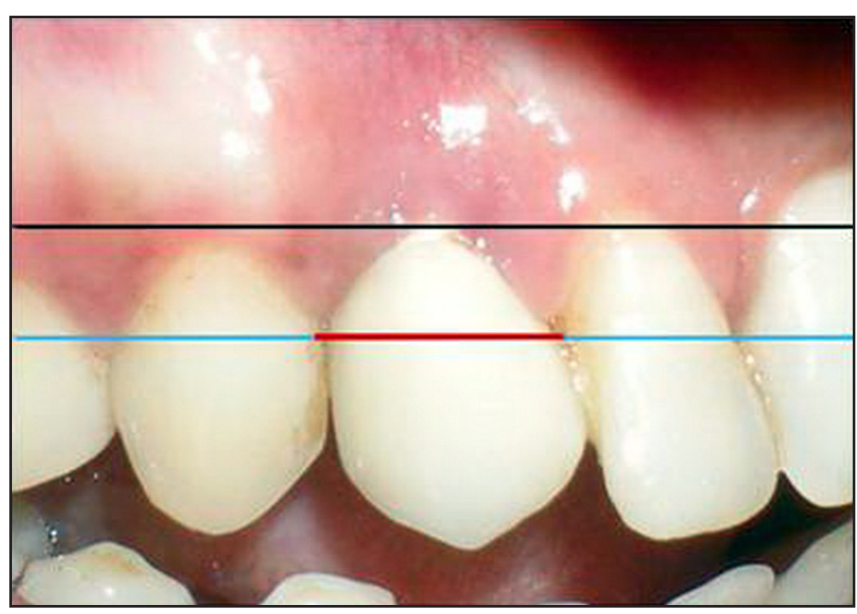

Figure 6. Papillae contour measurement at 6 months follow-up.

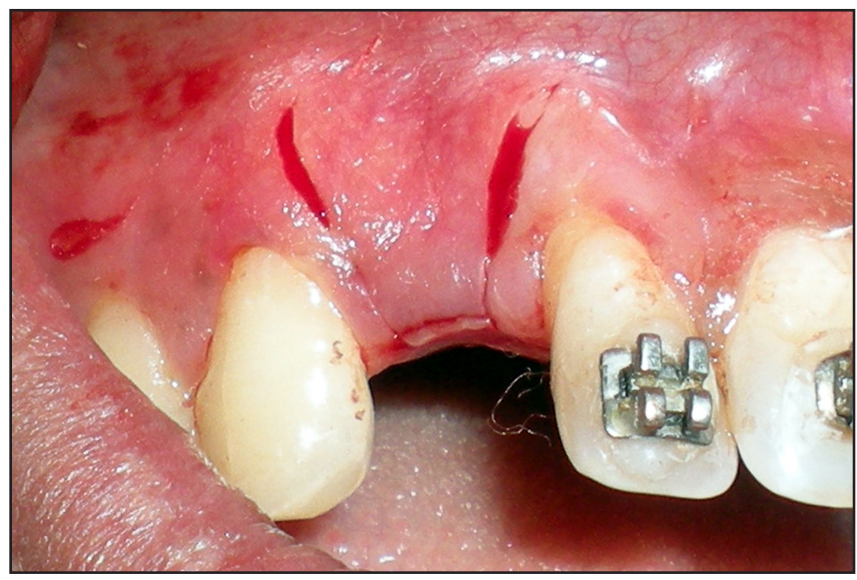

Figure 7. Incision excluding papillae of the adjacent teeth.

the correct dimensions. An incision was made in the palate that was parallel to the maxillary premolar and first molar at a distance of approximately $3 \mathrm{~mm}$ apical to the gingival margin. Perpendicular incisions were made to establish the width of the graft for covering the entire area of furcation. A flap was reflected to expose the underlying connective tissue. The SCTG was removed with a periosteal elevator. The graft was 
then placed on a sterile gauze pad and irrigated with saline. The SCTG was split into two triangular pieces and modified according the required dimensions.

\section{Preparation of recipient site}

Tunnelling was performed to create a pouch-like space beneath the buccal flap and a portion of palatal tissue (Figure 8) [7]. On the buccal aspect, pouch was extended by undermining the attached gingiva beyond mucogingival junction by \#15C blade. An intrasulcular incision was made around the necks of the teeth being treated. The incision was extended to adjacent tooth, both mesially and distally. This incision enabled access beneath the buccal gingiva and provided mobility to the pouch [18]. The cutting edge was directed toward the bone to dissect the connective tissue apical to the mucogingival line and free the buccal flap around each tooth. The papillae were also undermined carefully. The detached buccal gingiva could now move coronally since the connective tissue detachment was apical and into the mucosal tissue. The care was taken not to perforate the buccal gingiva. One piece of SCTG was inserted in the pouch created on mesial site of implant, while other on distal site of implant to protrude both the papillae $2-3 \mathrm{~mm}$ coronally $[\underline{7}, \underline{19}]$. A suture was placed at one end of the graft in guiding the graft while pushing through the sulcus and beneath each interdental papilla (Figure 9). The border of the each SCTG was gently pushed into the pouch using a tissue forceps and a packing instrument. The submerged SCTG was anchored in the interdental papillae area. An interrupted suture (4.0 Vicryl resorbable sutures) was used to hold the SCTG in position beneath the gingiva. The SCTG was submerged beneath the buccal flap while small portion of graft was kept exposed over papillary region (Figure 10).

After stabilization of both SCTG, the buccal flap was positioned around the implant and sutured to the palatal flap using a combination of inverted mattress and interrupted sutures to obtain primary closure (Figure 11). The inverted mattress sutures kept the bleeding edges of the flap together, while the interrupted sutures sealed the edges.

\section{Postoperative care}

Patients were prescribed antibiotics (Amoxicillin, $500 \mathrm{mg}$ tds for 1 week) and analgesics (Ibuprofen, $400 \mathrm{mg}$ bd for 1 week). Sutures were removed 7 to 10 days after surgery. Patients were instructed not to brush in the treated area and to rinse twice daily with chlorhexidine digluconate $0.12 \%$ (Periogard, Colgate) for 10 days. The final impression was made one week

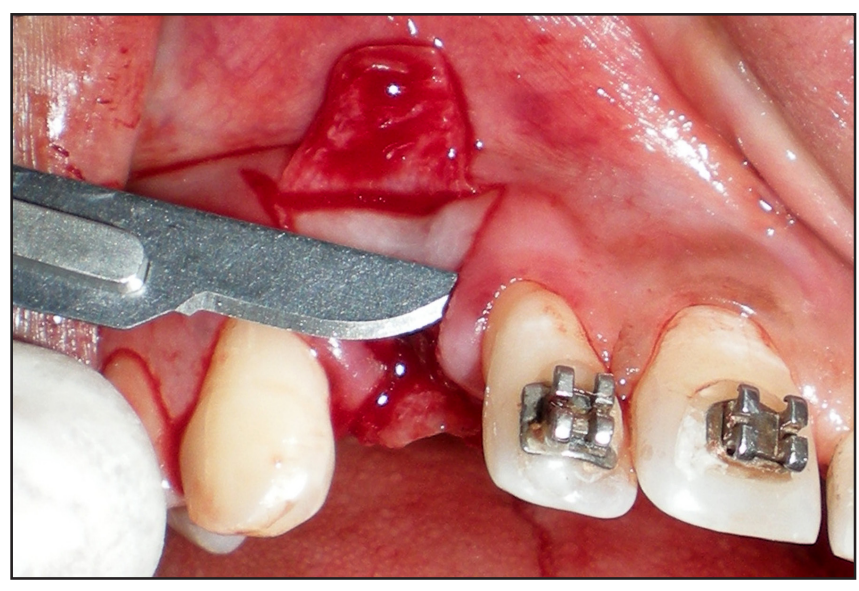

Figure 8. Tunnelling beneath the papilla creating a pouch.

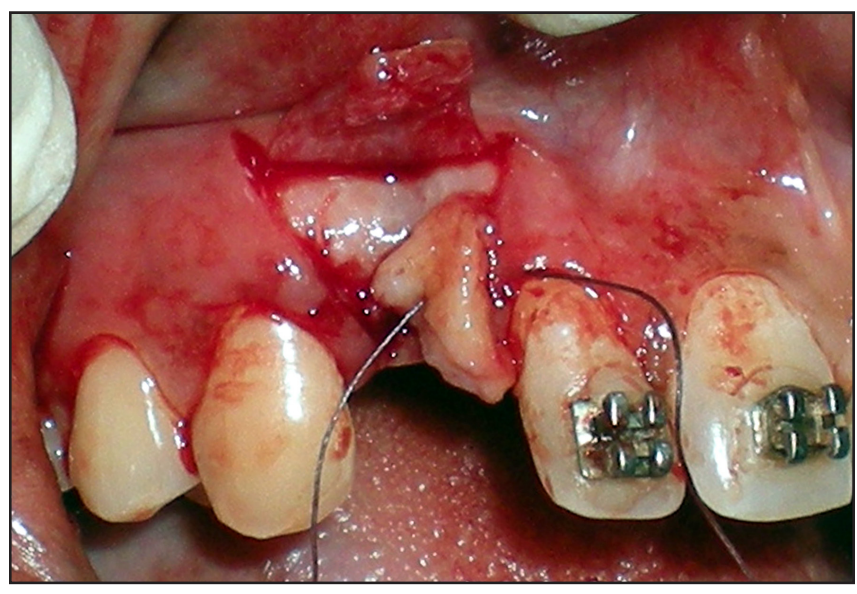

Figure 9. Suture placed to guide the graft beneath interdental papilla.

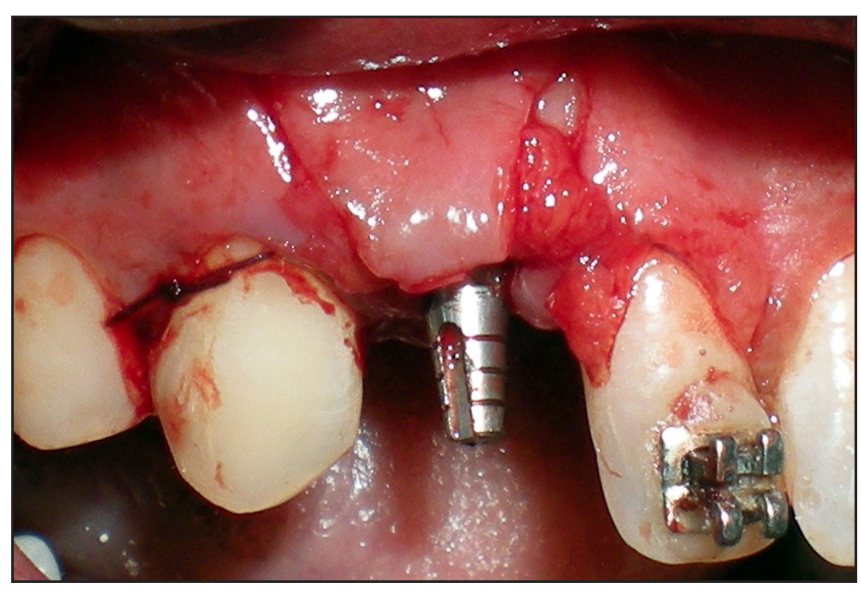

Figure 10. Connective tissue graft submerged beneath the flap.

after surgery using high viscosity vinyl polysiloxane. Within 15 days, an appropriate customized abutment was fixed and permanent restoration was finally cemented (Figure 12).

\section{Statistical analysis}

The means and standard deviations (M [SD]) values were calculated for all clinical parameters including 


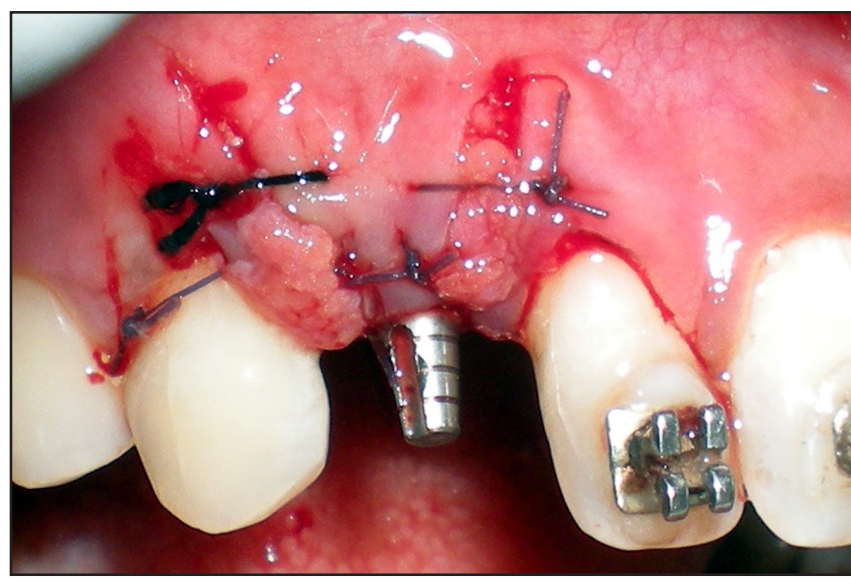

Figure 11. Connective tissue grafts after suturing.

PPD, CAL, GR, PI, PBI, and radiographic marginal bone loss (DIB). Parametric Student's paired test and non-parametric Wilcoxon test was used to compare data from baseline to those at 3 months and at 6 months for all the patients. The significance level was $\mathrm{P}<0.05$.

\section{RESULTS}

All implants achieved initial stability under $35 \mathrm{Ncm}$ of insertion torque. During the course of the study, wound healing was uneventful. No implants had to be removed. None of the selected patients had dropped out before the termination of the study.

\section{Clinical assessment}

The mean full mouth plaque index (FMPI) and full mouth papilla bleeding index (FMPBI) examination at 3 and 6 month study periods revealed continuous improvement (Table 1).

In all the patients, the mean PPD at 3 months of follow-up was 2.95 (SD 0.36) $\mathrm{mm}$ and at 6 months, it was reduced to 2.55 (SD 0.43) $\mathrm{mm}$ (Table 1).

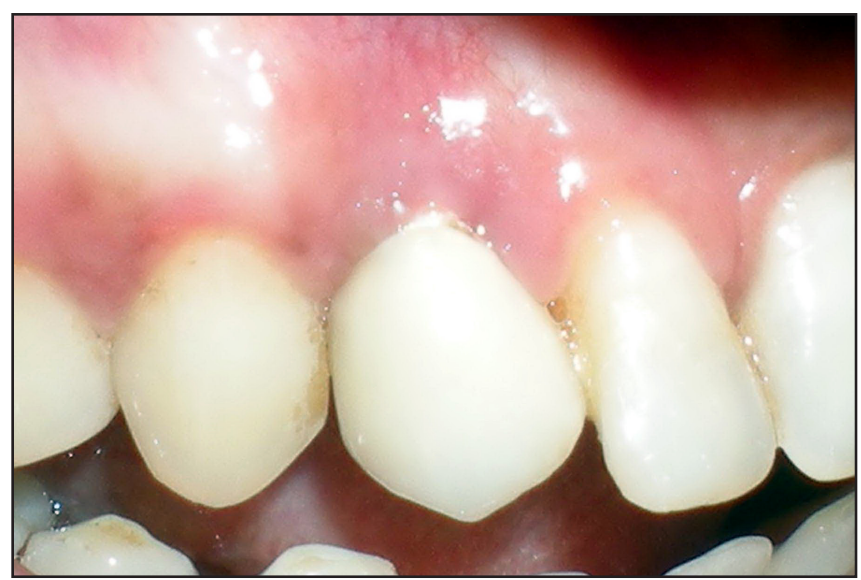

Figure 12. Final restoration placed.

Non-parametric Wilcoxon test indicated nonsignificant difference $(\mathrm{P}>0.05)$ in mean PPD reduction $(0.40$ [SD 0.56] $\mathrm{mm}$ ) between 3 to 6 months period.

The mean CAL of 2.85 (SD 0.47) $\mathrm{mm}$ was recorded at 3 months and 2.55 (SD 0.59) $\mathrm{mm}$ at 6 months of follow-up (Table 1). The mean CAL gain of 0.30 (SD 0.42) $\mathrm{mm}$ at 6 months period was nonsignificant $(\mathrm{P}>0.05)$.

The mean WKG at 3 months was $6.30(2.26) \mathrm{mm}$, which was slightly decreased at 6 months to 6.20 (SD 2.20) $\mathrm{mm}$ (Table 1). The difference in the WKG $(0.10$ [SD 0.31$] \mathrm{mm})$ between 3 and 6 months periods was nonsignificant $(\mathrm{P}>0.05)$.

\section{Radiographic assessment}

Radiographic crestal bone level (DIB) of mesial and distal surfaces of implants at baseline and bone loss at 3 and 6 months for all patients are presented in Table 2 . The evaluation of mean DIB at implant site on mesial surface at baseline $(3.5[\mathrm{SD} 0.70] \mathrm{mm})$ and at 3 months $(4.0$ [SD 0.66$] \mathrm{mm})$ revealed statistically significant $(\mathrm{P}=0.025)$ mean bone loss of 0.5 (SD 0.67) $\mathrm{mm}$. At 6 month period, the value of the DIB was increased to

Table 1. Comparison of clinical parameters at implant sites between 3 months and 6 months of follow-up

\begin{tabular}{lcccc}
\hline \multicolumn{1}{c}{ Clinical parameters } & $\begin{array}{c}\text { 3 months } \\
\text { M (SD) }\end{array}$ & $\begin{array}{c}\text { 6 months } \\
\text { M (SD) }\end{array}$ & $\begin{array}{c}\text { Difference } \\
\text { M (SD) }\end{array}$ & \multirow{2}{*}{ P value $^{\text {a }}$} \\
\hline Probing pocket depth (PPD) & $2.95(0.36)$ & $2.55(0.43)$ & $0.40(0.56)$ & $\mathrm{Ns}^{\mathrm{b}}$ \\
Clinical attachment level (CAL) & $2.85(0.47)$ & $2.55(0.59)$ & $0.30(0.42)$ & $\mathrm{Ns}^{\mathrm{b}}$ \\
Width of keratinized gingiva (WKG) & $6.30(2.26)$ & $6.20(2.20)$ & $0.10(0.31)$ & $\mathrm{Ns}^{\mathrm{b}}$ \\
Plaque index (PI) & $0.81(0.10)$ & $0.58(0.18)$ & $0.23(0.12)$ & $0.007^{\mathrm{c}}$ \\
Papillary bleeding index (PBI) & $0.84(0.10)$ & $0.49(0.20)$ & $0.36(0.16)$ & $0.008^{\mathrm{c}}$ \\
\hline
\end{tabular}

Tested between 3 and 6 months value.

${ }^{b}$ Nonsignificant, non-parametric Wilcoxon paired test.

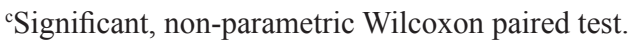

$\mathrm{M}(\mathrm{SD})=$ mean (standard deviation). 
Table 2. Changes of mean radiographic bone level $(\mathrm{mm})$ at implant site on mesial and distal surfaces from baseline to 3 and 6 months of follow-up

\begin{tabular}{cccccccc}
\hline Surface & Baseline & 3 months & Bone loss & P value $^{\mathrm{a}}$ & $\mathbf{6}$ months & Bone loss & $\mathrm{P}^{\mathrm{a}}$ value \\
\hline $\begin{array}{c}\text { Mesial } \\
\text { M (SD) }\end{array}$ & $3.5(0.70)$ & $4.0(0.66)$ & $0.5(0.67)$ & $\mathrm{P}=0.025^{\mathrm{b}}$ & $4.7(1.05)$ & $1.2(0.98)$ & $\mathrm{P}=0.01^{\mathrm{b}}$ \\
$\begin{array}{r}\text { Distal } \\
\text { M (SD) }\end{array}$ & $3.6(0.51)$ & $4.2(0.42)$ & $0.6(0.53)$ & $\mathrm{P}=0.034^{\mathrm{b}}$ & $5.4 \pm 1.17$ & $1.8(1.02)$ & $\mathrm{P}=0.007^{\mathrm{b}}$ \\
\hline
\end{tabular}

${ }^{a}$ Tested between baseline and at 3 and 6 months.

${ }^{b}$ Significant, non-parametric Wilcoxon paired test.

$\mathrm{M}(\mathrm{SD})=$ mean (standard deviation).

4.7 (SD 1.05) $\mathrm{mm}$ with the statistically significant $(\mathrm{P}=0.01)$ mean bone loss of $1.2(\mathrm{SD} 0.98) \mathrm{mm}$ in comparison to baseline data.

The mean DIB at distal implant surface at baseline was 3.6 (SD 0.51$) \mathrm{mm}$, and at 3 months of followup it increased to 4.2 (SD 0.42) $\mathrm{mm}$ with statistically significant $(P=0.034)$ mean bone loss of 0.6 (SD 0.53$) \mathrm{mm}$. At 6 months follow-up, the mean DIB was further increased to 5.4 (SD 1.17) $\mathrm{mm}$ with statistically significant $(\mathrm{P}=0.007)$ mean bone loss of 1.8 (SD 1.02) mm.

\section{Interproximal / interimplant papillae measurement Papillary height (PH) measurement}

The PH measurement of mesial and distal papilla of all individual patients at baseline, 3 months and 6 months of follow-up are shown in Table 3. The mean mesial $\mathrm{PH}$ at baseline was 2.30 (SD 0.48) $\mathrm{mm}$ and statistically significantly increased $(1.90$ [SD 0.87$] \mathrm{mm}, \mathrm{P}=0.005)$ at 3 months up to 4.20 (SD 0.91) mm. At 6 months of follow-up, mean mesial $\mathrm{PH}(3.80$ [SD 0.91] $\mathrm{mm})$ was slightly decreased as compared to 3 months; however, when comparison was made between 6 month and baseline $\mathrm{PH}$ value, the mean mesial $\mathrm{PH}$ was increased by 1.50 (SD 0.97) $\mathrm{mm}$ and the difference was found to be statistically significant $(\mathrm{P}=0.007)$.

The mean distal PH at baseline was 2.30 (SD 0.48) mm and at 3 months it increased (2 [SD 0.66 ] $\mathrm{mm}$, $\mathrm{P}=0.004)$ up to $4.3(\mathrm{SD} 0.67) \mathrm{mm}$. At 6 months period, mean distal $\mathrm{PH}(3.5$ [SD 0.70$] \mathrm{mm})$ was slightly decreased as compared to 3 months; however, when comparison was made between baseline and 6 month value, the mean distal $\mathrm{PH}$ was statistically significant increased by $1.2(\mathrm{SD} 0.78) \mathrm{mm}, \mathrm{P}=0.01$.

\section{Papillary contour (PC) measurement}

The PC measurement of mesial and distal papilla of all individual patients at baseline, 3 months and 6 months of follow-up are shown in Table 4. Only one patient showed complete loss of papilla on both mesial and distal surface due to severe interproximal bone loss at 6 month period.

Table 5 shows percentage of papilla index scores at baseline and follow-ups. The frequencies of scores $=0$ (failure) and 4 (hypertrophic) were $0 \%$ to both mesial and distal papilla. The frequency of a score $=1$ (aesthetic failure) was present at $70 \%$ for mesial and $60 \%$ for distal papilla at baseline and became only $10 \%$ for both mesial and distal papilla at 6 months postoperatively. The frequency of a score $=2$ (average aesthetic result) was present at $30 \%$ for mesial and $40 \%$ for distal papilla at baseline and became $30 \%$ for mesial and $50 \%$ for distal papilla at 3 months of follow-up. It improved at 6 months becoming $0 \%$ for mesial and $40 \%$ for distal

Table 3. Changes of papillary height ( $\mathrm{mm}$ ) from baseline to 3 and 6 months of follow-up

\begin{tabular}{cccccccc}
\hline Surface & Baseline & 3 months & Gain in PH & $\mathbf{P}^{\mathrm{a}}$ value & $\mathbf{6}$ months & Gain in PH & $\mathbf{P}^{\mathrm{a}}$ value \\
\hline $\begin{array}{c}\text { Mesial } \\
\text { M (SD) }\end{array}$ & $2.3(0.48)$ & $4.2(0.91)$ & $1.9(0.87)$ & $\mathrm{P}=0.005^{\mathrm{b}}$ & $3.8(0.91)$ & $1.5(0.97)$ & $\mathrm{P}=0.007^{\mathrm{b}}$ \\
$\begin{array}{c}\text { Distal } \\
\text { M (SD) }\end{array}$ & $2.3(0.48)$ & $4.3(0.67)$ & $2(0.66)$ & $\mathrm{P}=0.004^{\mathrm{b}}$ & $3.5(0.70)$ & $1.2(0.78)$ & $\mathrm{P}=0.01^{\mathrm{b}}$ \\
\hline
\end{tabular}

${ }^{\text {aT }}$ Tested between baseline and at 3 and 6 months.

${ }^{\mathrm{b} S i g n i f i c a n t, ~ n o n-p a r a m e t r i c ~ W i l c o x o n ~ p a i r e d ~ t e s t . ~}$

$\mathrm{M}(\mathrm{SD})=$ mean (standard deviation).

$\mathrm{PH}=$ papillary height. 
Table 4. Mean papilla index score at baseline, 3 months and 6 months of follow-up

\begin{tabular}{cccc}
\hline Surface & Baseline & 3 month & 6 month \\
\hline Mesial & $1.3(0.48)$ & $2.7(0.48)$ & $2.8(0.63)$ \\
M (SD) & & & \\
Distal & $1.4(0.51)$ & $2.5(0.52)$ & $2.4(0.69)$ \\
M (SD) & & \\
\hline
\end{tabular}

$\mathrm{M}(\mathrm{SD})=$ mean $($ standard deviation $)$.

Statistically significant $(\mathrm{P}<0.05$, non-parametric Wilcoxon paired test) papilla index score changes.

Table 5. Percentage of papilla index score at baseline, 3 months and 6 months of follow-up

\begin{tabular}{ccccccc}
\hline \multirow{2}{*}{ Time } & \multicolumn{2}{c}{$\begin{array}{c}\text { Score 1 } \\
\text { (aesthetic failure) }\end{array}$} & \multicolumn{2}{c}{$\begin{array}{c}\text { Score 2 } \\
\text { (average aesthetic) }\end{array}$} & \multicolumn{2}{c}{$\begin{array}{c}\text { Score 3 } \\
\text { (aesthetic success) }\end{array}$} \\
\cline { 2 - 7 } & Mesial & Distal & Mesial & Distal & Mesial & Distal \\
\hline Baseline & $70 \%$ & $60 \%$ & $30 \%$ & $40 \%$ & $0 \%$ & $0 \%$ \\
3 months & $0 \%$ & $0 \%$ & $30 \%$ & $50 \%$ & $70 \%$ & $50 \%$ \\
6 months & $10 \%$ & $10 \%$ & $0 \%$ & $0 \%$ & $90 \%$ & $90 \%$ \\
\hline
\end{tabular}

papilla. The frequency of a score 3 (aesthetic success) was $0 \%$ at baseline for both papillae while at 3 months, it improved to $70 \%$ for mesial and $50 \%$ for distal. At 6 months, it further improved to $90 \%$ for mesial and $50 \%$ for distal papilla.

\section{DISCUSSION}

The purpose of the present study was to evaluate the effectiveness of interproximal papillae reconstruction around single implant in maxillary anterior region by using SCTG. The study also emphasized the effectiveness of SCTG in terms of gain in vertical interproximal / interimplant papillary height and the success rate of early loaded implant by assessing periimplant changes using clinical and radiographic parameters. The results showed that papillae reconstruction procedure using SCTG at the time of implant placement resulted in statistically significant increase in papillary height in mesial and distal papilla and that functional loading of early implants as early as 15 days resulted in implant stability using clinical and radiographic measures.

Each patient showed good oral hygiene level and a healthy gingival condition throughout the duration of the study, as reflected by the low FMPI and FMPBI score.

In the present study, the survival rate of implants was found to be $100 \%$ at 6 months follow-up. Findings in the present study are comparable with previous reported studies. De Rouck et al. [15] assessed implant survival rate and aesthetic outcome 1 year after immediate placement and provisionalization of single-tooth implants in the maxillary anterior region and reported $97 \%$ success rate in 30 patients. Norton [16] reported $96.4 \%$ survival rate for immediately loaded implants with observation period of 20.3 months (range 13 - 30 months) after implant placement.

In the present study, the mean crestal bone loss at 6 months was found to be 1.2 (SD 0.98) $\mathrm{mm}$ and 1.8 (SD 1.02) $\mathrm{mm}$ on mesial and distal surface of implant respectively and is comparable with previous reported studies. Turkyilmaz et al. [17] reported the average marginal bone loss of $0.7 \mathrm{~mm}$ for one stage implant at one year recall. Schwartz et al. [18] reported statistically significant $(\mathrm{P}<0.05)$ bone loss around the implants placed in the maxilla, as compared to those in mandible in edentulous patients. Higher mean marginal bone loss on mesial and distal surfaces in the present study could be due to the fact that all the implants were placed in maxillary anterior region. Bone loss occurs mostly in first year after surgery, as reported by Weber et al. [19]. Authors showed that a large percentage of initial bone loss occurred during the first month in one stage implant [19]. After the first year of function, an immediate restoration did not seem to cause a greater average amount of bone loss.

In the present study, the mean CAL observed at 3 months was 2.85 (SD 0.47) $\mathrm{mm}$ and 2.55 (SD 0.59) $\mathrm{mm}$ at 6 months. The difference $(0.30$ [SD 0.42$] \mathrm{mm})$ between 3 months and 6 months values was not statistically significant $(\mathrm{P}>0.05)$. Similar observations have been made by several other investigators $[20,21]$.

Management of the papillae during implant placement does not always allow predictable soft tissue wound healing and aesthetic integration of the prosthetic crown. This may result in aesthetic failures. 
In the present study, papillae reconstruction was performed using SCTG during implant placement. $\mathrm{PH}$ as well as papillae contour measurements were recorded by using PIS [12].

In the present study, mean $\mathrm{PH}$ increased up to 1.9 (SD 0.87) $\mathrm{mm}$ and 2 (SD 0.66) $\mathrm{mm}$ for mesial and distal papilla respectively at 3 month after papillae reconstruction procedure. At 6 month, mean gain of $\mathrm{PH}$ decreased up to 1.5 (SD 0.007) $\mathrm{mm}$ for mesial papilla and 1.2 (SD 0.01) $\mathrm{mm}$ for distal papilla, due to shrinkage of soft tissue. Grossberg [4] attempted to reconstruct the papillae around implant by creating a midline double pedicle flap during second stage surgery and reported papillae reconstruction in 4 out of 12 patients in the range of 0.4 to $2.3 \mathrm{~mm}$. Though the mean papillary gain was not significant, he suggested the use of fixed reference line to assess the PH.

In the present study, $90 \%$ of the mesial papilla and $50 \%$ of distal papilla showed (PIS-3) complete regeneration while $10 \%$ of mesial papilla and $50 \%$ of distal papilla showed (PIS-2) partially regenerated papilla at 6 months follow-up. Price and Price [6] reported a case in which he used SCTG for soft tissue augmentation along with papillae reconstruction around single tooth implant restoration. Pouch was created within the buccal flap and SCTG were sutured and complete gingivopapillary unit was moved coronally. He reported completely filled papillae with provisional restoration provided considerable aesthetic results. Azzi et al. [7] created a pouch in the buccal flap and SCTG was inserted beneath the papillae and reported adequate thickening of the existing gingiva and successful reconstruction of interdental papillae around implant-supported restoration. In the present study, $90 \%$ of the mesial papillae and $50 \%$ of the distal papillae showed complete regeneration at 6 months follow-up. This difference could be explained by the fact that there was more marginal bone loss on distal surface $(1.8$ [SD 1.02)] mm) than mesial surface (1.2 [SD 0.98] $\mathrm{mm})$ at 6 months follow-up. Creating the aesthetic implant restoration is a multifaceted puzzle requiring ingenious treatment strategies. Further development in surgical techniques, microsurgery, tissue engineering, growth factor and implant material will assist us in achieving more predictable results in the future.

\section{CONCLUSIONS}

From the analysis of the results, and within the limitations of the present study, it can be concluded that a subepithelial connective tissue graft may be used to successfully augment the gingival papillae adjacent to single tooth restoration and that one stage early loading implant protocol resulted in predictable survival rate.

\section{ACKNOWLEDGMENTS AND DISCLOSURE STATEMENTS}

The authors declare that they have no conflict of interests.

\section{REFERENCES}

1. Albrektsson T, Gottlow J, Meirelles L, Ostman PO, Rocci A, Sennerby L. Survival of NobelDirect implants: an analysis of 550 consecutively placed implants at 18 different clinical centers. Clin Implant Dent Relat Res. 2007 Jun;9(2):65-70. [Medline: 17535329] [doi: 10.1111/j.1708-8208.2007.00054.x]

2. Testori T, Meltzer A, Del Fabbro M, Zuffetti F, Troiano M, Francetti L, Weinstein RL. Immediate occlusal loading of Osseotite implants in the lower edentulous jaw. A multicenter prospective study. Clin Oral Implants Res. 2004 Jun;15(3):278-84. [Medline: 15142089] [doi: 10.1111/j.1600-0501.2004.01013.x]

3. Hahn J. One-piece root-form implants: a return to simplicity. J Oral Implantol. 2005;31(2):77-84. [Medline: 15871526] [doi: $10.1563 / 0-737.1]$

4. Grossberg DE. Interimplant papilla reconstruction: assessment of soft tissue changes and results of 12 consecutive cases. J Periodontol. 2001 Jul;72(7):958-62. [Medline: 11495146] [doi: 10.1902/jop.2001.72.7.958]

5. Romeo E, Lops D, Rossi A, Storelli S, Rozza R, Chiapasco M. Surgical and prosthetic management of interproximal region with single-implant restorations: 1-year prospective study. J Periodontol. 2008 Jun;79(6):1048-55. [Medline: 18533782] [doi: 10.1902/jop.2008.070431]

6. Price RB, Price DE. Esthetic restoration of a single-tooth dental implant using a subepithelial connective tissue graft: a case report with 3-year follow-up. Int J Periodontics Restorative Dent. 1999 Feb;19(1):92-101. [Medline: 10379290]

7. Azzi R, Etienne D, Takei H, Fenech P. Surgical thickening of the existing gingiva and reconstruction of interdental papillae around implant-supported restorations. Int J Periodontics Restorative Dent. 2002 Feb;22(1):71-7. [Medline: 11922221]

8. Turesky S, Gilmore ND, Glickman I. Reduced plaque formation by the chloromethyl analogue of victamine C. J Periodontol. 1970 Jan;41(1):41-3. [Medline: 5264376] [doi: 10.1902/jop.1970.41.1.41] 
9. Mühlemann HR. Psychological and chemical mediators of gingival health. J Prev Dent. 1977 Jul-Aug;4(4):6-17. [Medline: 275483]

10. Lang NP, Mombelli A, Brägger U, Hämmerle CH. Monitoring disease around dental implants during supportive periodontal treatment. Periodontol 2000. 1996 Oct;12:60-8. Review. [Medline: 9567996] [doi: 10.1111/j.1600-0757.1996.tb00083.x]

11. Randow K, Ericsson I, Nilner K, Petersson A, Glantz PO. Immediate functional loading of Brånemark dental implants. An 18-month clinical follow-up study. Clin Oral Implants Res. 1999 Feb;10(1):8-15. [Medline: 10196785] [doi: 10.1034/j.1600-0501.1999.100102.x]

12. Jemt T. Regeneration of gingival papillae after single-implant treatment. Int J Periodontics Restorative Dent. 1997 Aug;17(4):326-33. [Medline: 9497723 ]

13. Reteitschak KH: Periodontology. In: Rateitschak KH, Rateitschak EM, Wolf MF, Hassell TM, editors: Color Atlas of Dental Medicline, 2nd edition, New York: Thieme Medical Publishers, Inc.; 1989. p. 1-48.

14. Azzi R, Etienne D, Carranza F. Surgical reconstruction of the interdental papilla. Int J Periodontics Restorative Dent. 1998 Oct;18(5):466-73. [Medline: 10093523]

15. De Rouck T, Collys K, Cosyn J. Immediate single-tooth implants in the anterior maxilla: a 1-year case cohort study on hard and soft tissue response. J Clin Periodontol. 2008 Jul;35(7):649-57. Epub 2008 Apr 16. [Medline: 18430047] [doi: 10.1111/j.1600-051X.2008.01235.x]

16. Norton MR. A short-term clinical evaluation of immediately restored maxillary TiOblast single-tooth implants. Int J Oral Maxillofac Implants. 2004 Mar-Apr;19(2):274-81. [Medline: 15101600]

17. Turkyilmaz I, Avci M, Kuran S, Ozbek EN. A 4-year prospective clinical and radiological study of maxillary dental implants supporting single-tooth crowns using early and delayed loading protocols. Clin Implant Dent Relat Res. 2007 Dec;9(4):222-7. [Medline: 18031444] [doi: 10.1111/j.1708-8208.2007.00045.x]

18. Schwartz-Arad D, Yaniv Y, Levin L, Kaffe I. A radiographic evaluation of cervical bone loss associated with immediate and delayed implants placed for fixed restorations in edentulous jaws. J Periodontol. 2004 May;75(5):652-7. [Medline: 15212346] [doi: 10.1902/jop.2004.75.5.652]

19. Weber HP, Buser D, Donath K, Fiorellini JP, Doppalapudi V, Paquette DW, Williams RC. Comparison of healed tissues adjacent to submerged and non-submerged unloaded titanium dental implants. A histometric study in beagle dogs. Clin Oral Implants Res. 1996 Mar;7(1):11-9. [Medline: 9002818] [doi: 10.1034/j.1600-0501.1996.070102.x]

20. Nishimura K, Itoh T, Takaki K, Hosokawa R, Naito T, Yokota M. Periodontal parameters of osseointegrated dental implants. A 4-year controlled follow-up study. Clin Oral Implants Res. 1997 Aug;8(4):272-8. [Medline: 9586473] [doi: $10.1034 / j .1600-0501.1997 .080404 . x$ ]

21. Behneke A, Behneke N, d'Hoedt B. The longitudinal clinical effectiveness of ITI solid-screw implants in partially edentulous patients: a 5-year follow-up report. Int J Oral Maxillofac Implants. 2000 Sep-Oct;15(5):633-45. [Medline: 11055130 ]

\section{To cite this article:}

Gupta S, Deo V, Williams C. Interproximal Papillae Reconstruction around Implant Using Subepithelial Connective Tissue Graft in Maxillary Anterior Region: A Case Series.

J Oral Maxillofac Res 2012;3(2):e1

URL: http://www.ejomr.org/JOMR/archives/2012/2/e1/v3n2e1ht.pdf

doi: $10.5037 /$ jomr.2012.3201

Copyright $($ C Gupta S, Deo V, Williams C. Accepted for publication in the JOURNAL OF ORAL \& MAXILLOFACIAL RESEARCH (http://www.ejomr.org), 10 April 2012

This is an open-access article, first published in the JOURNAL OF ORAL \& MAXILLOFACIAL RESEARCH, distributed under the terms of the Creative Commons Attribution-Noncommercial-No Derivative Works 3.0 Unported License, which permits unrestricted non-commercial use, distribution, and reproduction in any medium, provided the original work and is properly cited. The copyright, license information and link to the original publication on (http://www.ejomr.org) must be included. 